\title{
ANALISIS PERILAKU SCHOOL BULLYING DI SD MUHAMMADIYAH 17 SEMARANG
}

Oleh:

\author{
Trisca Camelia ${ }^{1}$, Eka Sari Setianingsih ${ }^{2}$, Diana Endah $\mathbf{H}^{3}$ \\ Universitas PGRI Semarang \\ Triscacamelia988@gmail.com
}

\begin{abstract}
Abstrak
Penelitian ini secara umum bertujuan untuk mengetahui perilaku-perilaku school bullying pada siswa kelas III di SD Muhammadiyah 17 Semarang. Penelitian menggunakan metode kualitatif dengan pendekatan deskriptif dan persentase. Penelitian ini dilakukan dengan cara menyebarkan angket untuk kelas III serta mewawancarai kepala sekolah, guru dan orang tua siswa di SD Muhammadiyah 17 Semarang. Berdasarkan hasil penelitian siswa kelas III SD Muhammadiyah 17 Semarang yang berjumlah 35 siswa dengan jumlah siswa laki-laki 26 anak dan perempuan 9 anak menjadi pelaku dan korban dari bullying. Korban bullying fisik terbanyak yang dilakukan siswa laki-laki yaitu dipukul dengan persentase $100 \%$, dan pada siswa perempuan yaitu didorong dengan persentase $88,9 \%$. Korban bullying verbal terbanyak pada siswa laki-laki yaitu diejek dengan persentase $96,2 \%$ dan pada siswa perempuan yaitu dibentak dengan persentase $89,9 \%$. Sedangkan pada bentuk bullying psikis pada siswa laki-laki yaitu diperlakukan gerak tubuh mengejek dengan persentase $80,2 \%$ dan pada siswa perempuan diteror dengan persentase 55,6\%. Sedangkan pelaku terbanyak bullying fisik pada siswa laki-laki yaitu memukul dengan persentase $69,2 \%$ dan pada siswa perempuan juga memukul dengan persentase $22,2 \%$. Pada bullying verbal terbanyak siswa laki-laki yaitu mengejek dengan persentase $73,1 \%$ dan pada siswa perempuan juga yaitu mengejek dengan persentase $33,3 \%$. Sedangkan pada bullying psikis pada siswa laki-laki yaitu meneror dengan persentase 42,3\% dan pada siswa perempuan yaitu melakukan gerak tubuh mengejek dengan persentase $22,2 \%$. Dampak terbanyak yang dialami siswa perempuan yaitu merasa trauma ketika dipukul dan pada siswa laki-laki yaitu terluka ketika dibully.
\end{abstract}

Kata Kunci: School Bullying.

Al-Madrasah: Jurnal Ilmiah Pendidikan Madrasah Ibtidaiyah Vol. 3, No. 2, Januari-Juni 2019 
Trisca Camelia, Eka Sari Setianingsih, Diana Endah H: Analisis Perilaku School Bullying di SD Muhammadiyah 17 Semarang

\begin{abstract}
This study generally aims to determine school bullying behaviors in class III students at Muhammadiyah Elementary School 17 Semarang. The study used qualitative methods with descriptive approaches and percentages. This research was conducted by distributing questionnaires to class III and interviewing principals, teachers and parents of students at Muhammadiyah 17 Elementary School Semarang. Based on the results of research in third grade students of Muhammadiyah 17 Semarang Elementary School, amounting to 35 students with 26 male students and 9 children as girls and perpetrators of bullying. The majority of victims of physical bullying were male students who were beaten with a percentage of $100 \%$, and female students were encouraged by the percentage of $88.9 \%$. The majority of verbal bullying victims were male students who were ridiculed with a percentage of $96.2 \%$ and female students who were shouted at a percentage of $89.9 \%$. Whereas in the form of psychological bullying in male students, they were treated with mocking gestures with a percentage of $80.2 \%$ and female students were terrorized with a percentage of $55.6 \%$. Whereas most perpetrators of physical bullying in male students were hit with a percentage of $69.2 \%$ and female students also hit with a percentage of $22.2 \%$. In verbal bullying, the majority of male students were mocking with a percentage of $73.1 \%$ and female students also mocking with a percentage of $33.3 \%$. Whereas psychic bullying in male students is terrorizing with a percentage of $42.3 \%$ and in female students that is mocking with a percentage of $22.2 \%$. The most impact experienced by female students is feeling traumatized when hit and on male students who are injured when bullied.
\end{abstract}

Keywords: School Bullying.

\title{
A. Pendahuluan
}

Sekolah dasar merupakan tahapan awal dalam pendidikan formal di Indonesia yang akan dilanjutkan dalam tahap pendidikan formal selanjutnya. Hal ini sesuai dengan Peraturan Menteri Pendidikan Nasional No.23 Tahun 2006 yang menyatakan bahwa "Pendidikan dasar memiliki tujuan untuk meletakkan dasar kecerdasan, pengetahuan, kepribadian, akhlak mulia serta keterampilan untuk hidup mandiri dan mengikuti pendidikan lebih lanjut".Berdasarkan kutipan ini, telah disebutkan bahwa pendidikan di Indonesia bertujuan untuk meletakkan dasar kecerdasan, pengetahuan, kepribadian, akhlak mulia serta keterampilan untuk hidup mandiri pada masing- 
Trisca Camelia, Eka Sari Setianingsih, Diana Endah H: Analisis Perilaku School Bullying di SD Muhammadiyah 17 Semarang

masing anak. Suatu yang mendasar sebagai bekal dalam mengikuti jenjang pendidikan selanjutnya ${ }^{1}$.

Ki Hajar Dewantara dalam Kongres Taman Siswa yang pertama pada tahun 1930 menyebutkan;

"Pendidikan umumnya berarti daya upaya untuk memajukan bertumbuhnya budi pekerti (kekuatan batin, karakter), pikiran (intelek), dan tubuh anak; dalam Taman Siswa tidak boleh dipisah-pisahkan bagian-bagian itu agar kita dapat memajukan kesempurnaan hidup, kehidupan dan penghidupan anak-anak yang kita didik selaras dengan dunianya."

Pendidikan merupakan upaya menumbuhkan budi pekerti, yaitu kekuatan batin serta karakter, pikiran, yaitu intelek, dan tubuh anak. Dalam upaya menumbuhkan budi pekerti yaitu pada kekuatan batin dan karakter anak merupakan upaya yang dilakukan untuk anak dalam menjalani kehidupan dimasyarakat kedepannya.

Pendidikan formal memiliki tujuan dalam pembentukan watak dan kepribadian anak. Menurut Undang-Undang No.20 Tahun 2003 tentang Sisdiknas, Pasal 3 menyatakan bahwa "Pendidikan nasional berfungsi mengembangkan kemampuan dan membentuk watak serta peradaban bangsa yang bermartabat dalam rangka mencerdaskan kehidupan bangsa, bertujuan untuk berkembangnya potensi peserta didik agar menjadi manusia yang beriman dan bertakwa kepada Tuhan Yang Maha Esa, berakhlak mulia, sehat, berilmu, cakap, kreatif, dan menjadi warga negara yang demokratis dan bertanggung jawab". 3

Berdasarkan Pasal 3 Sisdiknas diatas yaitu mengamanatkan bahwa pendidikan formal tidak hanya bertujuan mencerdaskan peserta didik dalam ranah kognitifnya saja, tetapi juga dalam ranah afektif dan psikomotoriknya

${ }^{1}$ Sistem Pendidikan Nasional. Undang-undang No.23 Tahun 2006

${ }^{2}$ Fuad Ihsan. Dasar-Dasar Kependidikan. (Jakarta: PT Rineka Cipta, 2003), h. 5.

3 Syamsu Yusuf, 2009. Landasan Bimbingan \& Konseling. (Bandung: PT Remaja Rosdakarya, 2009), h. 3. 
Trisca Camelia, Eka Sari Setianingsih, Diana Endah H: Analisis Perilaku School Bullying di SD Muhammadiyah 17 Semarang

yaitu agar peserta didik menjadi manusia yang beriman dan bertakwa kepada Tuhan Yang Maha Esa, berakhlak mulia, sehat, berilmu, cakap, kreatif, dan menjadi warga negara yang demokratis dan bertanggung jawab.

Dewasa ini orang tua menyerahkan sepenuhnya pendidikan anak kepada sekolah karena sibuknya oleh tuntutan kerja. Dengan demikian perkembangan anak terabaikan oleh orang tua karena hanya mengandalkan sekolah sebagai pelaku utama dalam mengembangkan potensi anak baik dalam ranah kognitif, afektif, maupun psikomotor. Padahal pendidikan pertama anak yaitu ada dalam keluarga khususnya pada pola asuh orang tua. Pembentukan watak dan kepribadian sejatinya berawal dari lingkungan keluarga. Masingmasing keluarga menerapkan pola asuh yang berbeda-beda. Penerapan pola asuh yang berbeda-beda disetiap keluarga membentuk perilaku anak yang berbeda-beda pula. Dengan demikian akan menjadi berat bagi sekolah apabila orang tua menyerahkan keseluruhan tugas pendidikan kepada sekolah.

Perilaku adalah sebuah gerakan yang diamati dari luar, seperti orang berjalan, naik sepeda, dan mengendarai motor atau mobil. Perilaku terdiri dari aktivitas-aktivitas yang berlangsung baik di dalam maupun di luar. Dengan demikian, perilaku manusia tentunya berbeda-beda berdasarkan pengaruh pembawaan, dan pengalaman pribadinya, setiap individu akan mengembangkan sifat-sifat dirinya dengan cara-cara yang berbeda. ${ }^{4}$

Dari pengertian diatas perilaku terbentuk oleh rangsangan. Sama halnya dengan anak, perilaku anak terbentuk oleh rangsangan atau pengaruh dari luar, seperti keluarga, lingkungan sekolah dan lingkungan masyarakat. Perluya lingkungan yang baik bagi anak dalam membentuk perilaku anak yang baik pula. Perilaku yang baik akan memberikan dampak positif dalam pendidikannya.

Perilaku dibedakan menjadi tiga yaitu perilaku moral, perilaku tak bermoral, dan perilaku amoral. Perilaku moral yaitu perilaku yang sesuai

\footnotetext{
${ }^{4}$ Frits Kluytmans. Perilaku Manusia (Pengantar Singkat tentang Psikologi).
} (Bandung: PT Refika Aditama,2006), h. 1. 
Trisca Camelia, Eka Sari Setianingsih, Diana Endah H: Analisis Perilaku School Bullying di SD Muhammadiyah 17 Semarang

dengan kode moral kelompok sosial. "moral” berasal dari kata latin mores, yang berarti tatacara, kebiasaan, dan adat. Perilaku moral merupakan pola perilaku yang diharapkan seluruh anggota kelompok sosial. Perilaku tak bermoral ialah perilaku yang tidak sesuai dengan harapan sosial, perilaku demikian tidak disebabkan ketidakacuhan akan harapan sosial melainkan ketidaksetujuan dengan standar sosial atau kurang adanya perasaan wajib menyesuaikan diri. Sedangkan perilaku amoral atau perilaku nonmoral yaitu perilaku yang disebabkan ketidakacuhan terhadap harapan kelompok sosial daripada pelanggaran sengaja terhadap standar kelompok. ${ }^{5}$

Perilaku agresif dapat digolongkan sebagai perilaku tak bermoral. Perilaku agresif dapat dipahami sebagai suatu perilaku yang bertujuan untuk melukai orang lain, baik secara verbal maupun nonverbal, secara fisik, maupun psikis, langsung, maupun tidak langsung. Perilaku agresif bukan hanya melekat pada kaum dewasa, tetapi bibit-bibit agresivitas telah dapat kita jumpai dalam perilaku anak dalam kehidupan keseharian mereka. ${ }^{6}$

Komisi Perlindungan Anak Indonesia (KPAI) menyatakan keprihatinan dalam peringatan Hari Pendidikan Nasional tahun 2018. Persoalannya, KPAI mencatat ada 84 persen siswa di Indonesia yang pernah mengalami kekerasan di sekolah. "Kekerasan di satuan pendidikan cukup tinggi, baik yang dilakukan guru pada siswa, siswa terhadap guru, maupun siswa terhadap siswa lainnya," kata Komisioner Bidang Pendidikan KPAI Retno Listyarti melalui siaran persnya pada Rabu 2 Mei 2018. Berdasarkan data KPAI, 40 persen siswa usia 13-15 tahun melaporkan pernah mengalami kekerasan fisik oleh teman sebaya. Sedangkan 75 persen siswa mengaku pernah melakukan kekerasan di sekolah. Selain itu, 50 persen anak melaporkan mengalami perundungan (bullying) di sekolah.. Kekerasan tersebut tidak hanya dilakukan oleh siswa tetapi juga guru dan petugas sekolah. Ada sebanyak 45 persen siswa laki-laki dan 22 siswa

\footnotetext{
${ }^{5}$ Elizabeth B. Hurlock. Perkembangan Anak. (Penerbit Erlangga, 1989), h. 74.
}

${ }^{6}$ Antasari. Menyikapi Perilaku Agresif Anak. (Yogyakarta: Kanisius, 2006), h. 8. 
Trisca Camelia, Eka Sari Setianingsih, Diana Endah H: Analisis Perilaku School Bullying di SD Muhammadiyah 17 Semarang

perempuan menyebutkan bahwa guru atau petugas sekolah merupakan pelaku kekerasan. KPAI juga mencatat dalam tri semester pertama di 2018, pengaduan di KPAI didominasi kekerasan fisik dan anak korban kebijakan, yaitu sebesar 72 persen. Sedangkan 9 persen siswa mengadu karena kekerasan psikis, empat persen karena pemalakan, dan dua persen karena kekerasan seksual. ${ }^{7}$

Akhir-akhir ini kasus kekerasan di sekolah juga semakin marak ditemui baik di media cetak maupun media elektronik. Bahkan kekerasan yang merupakan bentuk perilaku agresif ini telah mengarah kepada tindak kriminal. Lebih parahnya, pelakunya adalah seorang anak seusia sekolah dasar. TA, 12 tahun siswa kelas lima Sekolah Dasar Negeri Pakunden Kota Kediri yang menjadi korban perisakan akhirnya dirujuk ke RSUD Dr Soetomo Surabaya. Korban diduga mengalami infeksi otak dan sakit pada kemaluannya setelah dianiaya tujuh temannya di halaman sekolah. Data yang diterima Dinas Pendidikan Kota Kediri menyebutkan peristiwa perisakan ini terjadi pada tanggal 18 Januari 2018 lalu. Kala itu TA bersama teman-temannya tengah bertanding sepak bola saat jam istirahat di halaman sekolah. Secara tak sengaja TA melakukan gol bunuh diri yang memicu kemarahan teman-temannya. ${ }^{8}$

Bentuk penyimpangan perilaku yang terjadi pada siswa sekolah dasar tidak hanya berupa kekerasan yang merupakan salah satu bentuk dari perilaku agresif. Pada kenyataannya, hal-hal yang kita pandang sebagai perilaku yang wajar dilakukan anak usia SD pun terkadang tergolong dalam penyimpangan perilaku. Mulai hanya sekedar mengolok-olok temannya, memelototi teman, hingga mencoreti hiasan kelas.

7 Hilmi, A. 2018, Mei 2. Tempo. Retrieved from Tempo.co:https://nasional.tempo.co/read/1084922/hari-pendidikan-kpai-84persensiswa-alami-kekerasan-di-sekolah/full\&view=ok. Di unduh tanggal 29/10/2018 pukul 23:25 WIB.

8 Wasono, H. T. 2018, Januari 29. Tempo. Retrieved from Tempo.co:https://nasional.tempo.co/read/1055133/siswa-sd-di-kediri-jadi-korbanbullying-alami-infeksi-otak/full\&view=ok. Di unduh tanggal 29/01/2018 pukul 12:56 WIB. 
Trisca Camelia, Eka Sari Setianingsih, Diana Endah H: Analisis Perilaku School Bullying di SD Muhammadiyah 17 Semarang

Bentuk-bentuk penyimpangan perilaku tersebut dapat dikatakan sebagai perilaku "Bullying". Menurut Komisi Perlindungan Anak bullying adalah kekerasan fisik dan psikologis berjangka panjang yang dilakukan seseorang atau sekelompok terhadap seseorang yang tidak mampu mempertahankan diri. Bullying dilakukan dalam situasi dimana ada hasrat untuk melukai, menakuti, atau membuat orang lain merasa tertekan, trauma, depresi, dan tak berdaya. ${ }^{9}$

Schoool Bullying merupakan perilaku agresif yang dilakukan berulangulang oleh seseorang/sekelompok siswa yang memiliki kekuasaan terhadap siswa/siswi lain yang lebih lemah dengan tujuan menyakiti. ${ }^{10}$

Contoh perilaku bullying antara lain mengejek, menyebarkan rumor, menghasut, mengucilkan, menakut-nakuti (intimidasi), mengancam, menindas, memalak, atau menyerang secara fisik (mendorong, menampar, atau memukul). Sebagian orang mungkin berpendapat bahwa perilaku bullying tersebut merupakan hal sepele atau bahkan normal dalam tahap kehidupan manusia atau dalam kehidupan sehari-hari. ${ }^{11}$

Namun faktanya, perilaku bullying merupakan learned behaviors karena manusia tidak terlahir sebagai penggertak dan pengganggu yang lemah. Bullying merupakan perilaku yang tidak normal, tidak sehat, dan secara sosial tidak dapat diterima. Hal yang sepele pun kalau dilakukan secara berulang kali pada akhirnya dapat menimbulkan dampak serius dan fatal. Dengan membiarkan atau menerima perilaku bullying, kita berarti memberikan bullies power kepada pelaku bullying, menciptakan interaksi sosial yang tidak sehat dan meningkatkan budaya kekerasan. Interaksi sosial yang tidak sehat dapat menghambat pengembangan potensi diri secara optimal sehingga memandulkan budaya unggul. ${ }^{12}$

9 Fitria Chakrawati. Bullying Siapa Takut. (PT Tiga Serangkai Pustaka Mandiri, 2015), h. 11.

${ }^{10}$ Novan ArdyWiyani. Save Our Children From School Bullying. (Jogjakarta: Ar-Ruzz Media, 2014), h. 8.

${ }^{11}$ Ibid., h. 12.

${ }^{12}$ Ibid.,h. 13. 
Trisca Camelia, Eka Sari Setianingsih, Diana Endah H: Analisis Perilaku School Bullying di SD Muhammadiyah 17 Semarang

Peristiwa kekerasan dalam dunia pendidikan merupakan peristiwa yang sering terjadi. Sekolah seharusnya memberikan rasa aman dan nyaman bagi seorang anak dalam belajar. Pemerintah sudah mengatasi kasus ini dengan adanya UU No. 23 tahun 2002 pasal 54 "Anak didalam dan di lingkungan sekolah wajib dilindungi dari tindakan kekerasan yang dilakukan oleh guru, pengelola sekolah dan teman-temannya didalam sekolah yang bersangkutan atau lembaga pendidikan lainnya" dari tujuan tersebut anak wajib dilindungi dari tindak kekerasan di sekolah. ${ }^{13}$

Berdasarkan hasil observasi dan wawancara dengan kepala sekolah di SD Muhammadiyah 17 Semarang khususnya di kelas III, tindakan bullying kerap terjadi. Sesuai penuturan kepala sekolah, memang di kelas III sangat terkenal kenakalan dan kegaduhannya. Hampir seluruh siswa laki-laki di kelas III sangat ramai saat kegiatan pembelajaran berlangsung maupun saat jam pelajaran kosong dan saat jam istirahat berlangsung. Ramai dalam hal ini bukan aktif belajar, melainkan mereka saling mengejek, menyebarkan rumor, mengucilkan, bertengkar, dan membuat seluruh siswa terpengaruh. Dengan keadaan tersebut tentunya membuat kegiatan pembelajaran serta lingkungan kelas yang tidak kondusif. Siswa kelas III yang beranggotakan 35 anak yang didominasi oleh siswa laki-laki dengan jumlah 26 anak, dan siswa perempuan dengan jumlah hanya 9 anak. Hal tersebut juga dapat menjadi salah satu penyebab kerap terjadi perilaku bullying di kelas tersebut.

\section{B. Metode Penelitian}

Penelitian ini dilaksanakan di SD Muhammadiyah 17 Semarang . Penelitian ini dilakukan pada tanggal 16, 18, 20, 29, 30, April 2019 dan tanggal 2 Mei 2019 pada tahun pembelajaran 2018/2019.

Rumusan masalah dalam penelitian ini adalah apa saja perilaku school bullying pada siswa kelas III di SD Muhammadiyah 17 Semarang dan tujuannya

\footnotetext{
${ }^{13}$ Sistem Pendidikan Nasional. Undang-undang No.23 Tahun 2002. Pasal 54
} 
Trisca Camelia, Eka Sari Setianingsih, Diana Endah H: Analisis Perilaku School Bullying di SD Muhammadiyah 17 Semarang

yaitu untuk mengetahui perilaku-perilaku school bullying pada siswa kelas III di SD Muhammadiyah 17 Semarang . Penelitian menggunakan metode kualitatif dengan pendekatan deskriptif dan persentase.

Penelitian ini dilakukan dengan menggunakan beberapa metode pengumpulan data diantaranya data angket atau kuesioner, wawancara, observasi dan dokumentasi. Angket atau kuesioner digunakan peneliti untuk mengetahui berbagai macam bentuk bullying, faktor penyebab bullying serta dampak yang ditimbulkannya.

Agar memudahkan penelitian, bentuk-bentuk bullying, faktor penyebab bullying dan dampaknya dari hasil data angket yang telah diisi siswa kelas III SD Muhammadiyah 17 Semarang dipersentasekan dengan rumus presentase yang dikemukan oleh Sudjono sebagai berikut: ${ }^{14}$

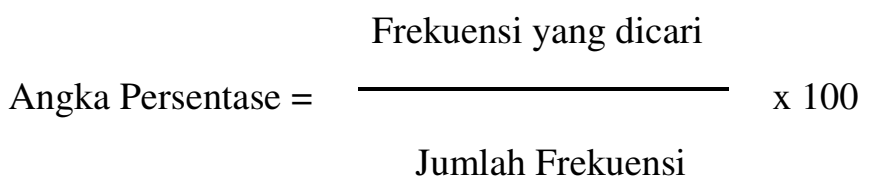

Selanjutnya peneliti menganalisis persentase dari hasil data angket, wawancara, dan observasi yang kemudian mendeskripsikannya dengan katakata hingga menarik kesimpulan hasil penelitian yang telah dilakukan.

\section{Hasil dan Pembahasan}

SD Muhammadiyah 17 Semarang merupakan sekolah dasar yang berada di Jalan Medoho Raya No. 118, Kelurahan Sambirejo, Kecamatan Gayamsari, Kota Semarang terdiri dari 6 kelas yaitu kelas 1 sampai dengan kelas 6 terdiri dari berbagai macam watak serta latar belakang orang tua yang berbeda. Penelitian ini difokuskan pada siswa kelas III dengan menganalisis perilaku school bullying yang terjadi di SD Muhammadiyah 17 Semarang. 2010), h. 43.

14 Anas Sudjono. Pengantar Statistika Pendidikan. (Jakarta: Rajawali Pers, 
Trisca Camelia, Eka Sari Setianingsih, Diana Endah H: Analisis Perilaku School Bullying di SD Muhammadiyah 17 Semarang

Berdasarkan deskripsi data hasil penelitian yang telah terkumpul maka langkah selanjutnya ialah pembahasan dari hasil penelitian tentang perilaku school bullying di SD Muhammadiyah 17 Semarang di paparkan sebagai berikut:

\section{Bentuk-bentuk Bullying}

Berdasarkan beberapa data hasil angket pada siswa kelas III dapat diketahui bahwa bullying merupakan perilaku agresif atau tindakan untuk melukai orang lain yang dilakukan secara sengaja maupun tidak sengaja untuk menyakiti. Sesuai dengan teori Wiyani yang menyatakan bahwa bullying adalah perilaku agresif atau negatif yang dilakukan seseorang atau sekelompok orang secara berulangkali yang menyalahgunakan ketidakseimbangan kekuatan dengan tujuan menyakiti targetnyasecara mental atau secara fisik. ${ }^{15}$

Berdasarkan hasil angket siswa kelas III yang berjumlah 35 siswa yang terdiri dari 26 laki-laki dan 9 perempuan menempatkan diri sebagai korban dan pelaku bullying dengan perolehan persentase yang berbedabeda antara siswa laki-laki dan siswi perempuan kelas III di SD Muhammadiyah 17 Semarang. Berdasarkan hasil presentase diketahui bahwa siswa laki-laki yang menjadi korban bullying terbanyak yaitu bentuk bullying fisik yaitu dipukul karena 100\% (26 siswa) mengaku pernah dipukul oleh temannya dengan berbagai alasan yaitu seperti mengejek, bertengkar, jahil dan memang pelaku nakal dan sebanyak 92,3\% (24 siswa) mengatakan pernah ditendang oleh temannya dengan berbagai alasan seperti. Sedangkan siswa perempuan yang menjadi korban bullying terbanyak juga pada bentuk bullying fisik yaitu didorong, karena $88,9 \%$ (8 siswa) mengatakan pernah didorong oleh temannya dengan berbagai alasan seperti karena lama mengaji, jahil dan tidak meminjamkan peralatan/alat tulis. Selain didorong siswa perempuan

${ }^{15}$ Novan ArdyWiyani. Save Our Children From School Bullying. (Jogjakarta: Ar-Ruzz Media, 2014), h. 14. 
Trisca Camelia, Eka Sari Setianingsih, Diana Endah H: Analisis Perilaku School Bullying di SD Muhammadiyah 17 Semarang

sebanyak 88,9\% (8 siswa) juga mengatakan pernah ditendang dengan berbagai alasan seperti memang pelaku nakal dan korban memang bersalah.

Berdasarkan hasil persentase juga diketahui persentase terbanyak korban bullying verbal pada siswa perempuan yaitu dibentak, karena sebanyak $88,9 \%$ siswa mengatakan pernah dibentak temannya dengan berbagai alasan yaitu seperti karena korban tidak meminjamkan pensil, korban diperintah untuk mengambilkan barang dan karena pelaku galak. Sedangkan pada siswa laki-laki persentase bullying verbal terbanyak yaitu diberi nama panggilan khusus/nama orangtua, karena sebanyak 73,1\% (19 siswa) mengatakan pernah diberi nama panggilan khusus/nama panggilan orangtua oleh temannya, dengan berbagai alasan yaitu seperti karena pelaku mengetahui nama orangtuanya dan karena pelaku nakal.

Persentase terbanyak korban bullying psikis yang dialami siswa laki-laki yaitu siswa diperlakukan gerakan tubuh mengejek oleh temannya. Sebanyak $80,8 \%$ siswa laki-laki mengatakan pernah diperlakukan gerakan tubuh mengejek oleh temannya. Sedangkan pada siswa perempuan persentase terbanyak bullying psikis yaitu sama dengan siswa laki-laki yaitu diperlakukan gerakan tubuh mengejek oleh temannya, karena sebanyak 55,6\% (5 siswa) siswa perempuan mengatakan pernah diperlakukan hal tersebut, selain perlakukan itu sebanyak 55,6\% siswa perempuan juga mengaku pernah diancam oleh temannya dengan berbagai alasan yaitu seperti karena korban pernah melakukan kesalahan pada pelaku dan korban tidak mau bermain dengan pelaku.

Selain menjadi korban, siswa kelas III di SD Muhammadiyah 17 Semarang juga tentunya pernah menjadi pelaku tindakan bullying. Berdasarkan hasil presentase diketahui bahwa siswa laki-laki yang menjadi pelaku bullying terbanyak yaitu bentuk bullying verbal yaitu mengejek karena 73,1\% (19 siswa) mengaku pernah mengejek temannya 
Trisca Camelia, Eka Sari Setianingsih, Diana Endah H: Analisis Perilaku School Bullying di SD Muhammadiyah 17 Semarang

dengan berbagai alasan seperti karena korban menendang pelaku, karena korban mengejeknya duluan, dan karena korban mengejek orangtua pelaku. Sedangkan pada siswa perempuan angka persentase menjadi pelaku tindakan bullying cenderung rendah. Angka persentase tertinggi pelaku bullying pada siswa perempuan yaitu pada bentuk bullying verbal yaitu mengejek dan memberi nama pamggilan khusus atau nama panggilan orangtua pada teman. Sebanyak 33,3\% (3 siswa) siswa perempuan mengatakan pernah menjadi pelaku bullying verbal mengejek dan memberi nama panggilan khusus atau nama panggilan orangtua pada teman dengan berbagai alasan yaitu karena korban mengejek pelaku terlebih dahulu sehingga pelaku membalasnya dan pelaku malu orangtuanya diejek oleh korban sehingga pelaku juga melakukan hal yang sama. Dilihat dari alasan tersebut bahwa siswa menjadi pelaku bullying cenderung karena membalas perlakuan dari si korban, dan juga dapat terjadi sebaliknya, korban membalas pelaku sehingga korban bullying pun dapat menjadi pelaku bullying.

Selain bullying verbal, jumlah siswa laki-laki yang melakukan bullying fisik juga cukup besar, yaitu sebanyak 18 siswa laki-laki $(69,2 \%)$ mengakui pernah memukul temannya dengan berbagai alasan yaitu karena korban mengejeknya, karena korban nakal, dan karena korban bersalah. Sedangkan pada siswa perempuan hanya 2 siswa $(22,2 \%)$ yang mengatakan pernah memukul temannya. Hal tersebut dapat dilihat saat dilakukannya penelitian, siswa perempuan dikelas III memang cenderung diam dan tidak terlihat melakukan perilaku bullying fisik, karena dikelas III cenderung siswa laki-lakinya yang terlihat mengganggu teman yang lainnya sehingga terjadi perilaku bullying fisik.

Siswa kelas III juga mengaku menjadi pelaku bullying psikis yaitu 42,3\% siswa laki-laki (11 siswa) mengatakan pernah meneror temannya dengan salah satu alasan pelaku mengaku jahil melakukannya. 
Trisca Camelia, Eka Sari Setianingsih, Diana Endah H: Analisis Perilaku School Bullying di SD Muhammadiyah 17 Semarang

Sedangkan 2 siswa perempuan (22,2\%) mengaku pernah melakukan gerak tubuh mengejek pada temannya dengan alasan karena korban nakal.

Berdasarkan analisis wawancara guru di SD Muhammadiyah 17 Semarang juga diketahui beberapa bentuk-bentuk bullying yang ada dikelas III yaitu berdasarkan wawancara dengan Ibu Ninik Riwayati bentuk bullying fisik berupa memukul, mencubit, bahkan pernah ada kasus pensil (ujungnya) menancap dikepala anak. Bentuk bullying verbal yang terjadi yaitu seperti saling mengejek, seperti mengejek pekerjaan orangtua, mengejek nama orangtua, mengejek kondisi fisik teman. Sedangkan pada bentuk bullying psikis menurut Ibu Ninik Riwayati tidak terjadi. Bentuk-bentuk bullying tersebut terjadi pada waktu-waktu fleksibel seperti istirahat atau pergantian jam pelajaran saat tidak ada guru yang mengawasi, tetapi terkadang juga terjadi dikelas saat ada gurupun terjadi tetapi bentuknya lebih ringan.

Hasil penelitian pada siswa dan siswi kelas III di SD Muhammadiyah 17 Semarang menunjukkan bahwa di SD Muhammadiyah 17 Semarang terjadi bullying yang meliputi bullying fisik, bullying verbal, dan bullying psikis. Pada siswa laki-laki perilaku bullying yang dilakukan lebih sering pada bullying fisik, verbal dan psikis seperti memukul, memeras, membentak, mengejek, dan mengancam. Sedangkan pada siswi perempuan lebih banyak menjadi korban bullying fisik namun hanya seperti dipukul secara bercanda, dan bullying psikis yaitu diiejek dan diancam. Hasil penelitian ini sesuai dengan teori bentukbentuk bullying yang dikemukakan oleh Chakrawati (2015 :12) bentuk bullying secara garis besar dibedakan menjadi tiga yaitu bullying fisik,bullying verbal dan bullying psikis. ${ }^{16}$

Berdasarkan analisis diperoleh bahwa perilaku bullying anak di SD Muhammadiyah 17 Semarang disebabkan karena adanya perilaku

16 Fitria Chakrawati. Bullying Siapa Takut. (PT Tiga Serangkai Pustaka Mandiri, 2015), 12. 
Trisca Camelia, Eka Sari Setianingsih, Diana Endah H: Analisis Perilaku School Bullying di SD Muhammadiyah 17 Semarang

membalas serta adanya keingin untu melukai sehingga adanya dorongan untuk menyakiti orang lain. Hasil penelitian ini sesuai dengan pengertian bullying yang dikemukakan oleh Wiyani (15, 2010) yang mengatakan bahwa bullying merupakan perilaku yang bertujuan menyakiti korban baik secara fisik maupun mental. ${ }^{17}$

\section{Faktor Penyebab Bullying}

\section{a) Faktor Keluarga}

Berdasarkan hasil persentase angket siswa mengenai faktor penyebab terjadinya bullying yaitu faktor keluarga dengan pernyataan "orangtua saya bertengkar didepan saya" sebanyak 44,4\% (4 siswa) siswa perempuan mengatakan ya dan $34,6 \%$ (9 siswa) siswa laki-laki mengatakan ya. Berdasarkan hasil angket tersebut disesuaikan dengan hasil wawancara dengan orangtua siswa dan terdapat hasil yang tidak sesuai antara siswa dengan orangtua siswa salah satunya berdasarkan pengakuan siswa bernama Intan Ayu Nawangsih melalui angket yang diberikan dia mengatakan pernah melihat orangtuanya bertengkar didepannya, tetapi saat dilakukannya wawancara dengan orangtua Intan yaitu Ibu Ningsih mengatakan tidak pernah bertengkar didepan anak. Pengaruh keluarga terutama orangtua merupakan pengaruh terbesar bagi anak terutama dalam tindakan bullying. Perlunya perhatian, bimbingan dan contoh yang baik dari orangtua untuk anak dalam meminimalisir anak melakukan tindakan bullying yang dapat dilakukan berdasarkan apa yang mereka lihat dari orang terdekatnya terutama orangtua. Sedangkan pada pernyataan "saudara saya memusuhi saya dan saya pun memusuhinya" sebanyak 38,5\% (10 siswa) siswa laki-laki mengatakan ya dan hanya 11,1\% (1 siswa) siswa perempuan mengatakan ya. Pernyataan tersebut juga didukung

${ }^{17}$ Novan Ardy Wiyani. Save Our Children From School Bullying. (Jogjakarta: Ar-Ruzz Media, 2014), h. 15. 
Trisca Camelia, Eka Sari Setianingsih, Diana Endah H: Analisis Perilaku School Bullying di SD Muhammadiyah 17 Semarang

oleh pernyataan beberapa orangtua yang mengatakan anaknya pernah bertengkar dengan saudaranya.

Berdasarkan wawancara dengan guru kelas yaitu Ibu Fienda Novita selaku wali kelas III, siswa yang melakukan perilaku bullying kebanyakan dari keluarga yang bermasalah. Seperti Ridho yang ayahnya diluar jawa mengakibatkan kurangnya perhatian yang diberikan, hal tersebut juga didukung dengan hasil wawancara dengan orangtua Ridho yaitu Ibu Legianti, Ridho merupakan anak pertama dari 2 bersaudara, adiknya masih berumur 2 tahun sedangkan Ibu Legianti dalam kondisi mengandung anak ke 3, dan berdasarkan pengamatan peneliti bisa dikatakan Ridho merupakan keluarga yang "kurang memiliki" dilihat dari kondisi rumahnya. Ibu Legianti merupakan ibu rumah tangga yang berumur 36 tahun. Ibu Legianti hanya tinggal bersama anak-anaknya yaitu Ridho dan adiknya. Berdasarkan hasil wawancara ibu Legianti mengaku tidak begitu mengerti perilaku yang dilakukan Ridho saat disekolah, karena saat dirumah Ridho berkelakuan baik dan seringnya bermain diluar rumah. Tetapi berdasarkan hasil wawancara dengan guru TU Ibu Ninik Riwayati salah satu siswa kelas III yang pernah dihukum karena kesalahannya yaitu Ridho, menurut penuturan Ibu Ninik Riwayati Ridho merupakan siswa yang diam tetapi nakal, dia pernah ketahuan membawa handphone disekolah dan pernah kedapatan memalsukan tanda tangan wali kelasnya.

Berdasarkan analisis tersebut dapat terlihat bahwa masih kurangnya pengawasan orangtua sehingga mengakibatkan anak melakukan tindakan pelanggaran. Faktor keluarga merupakan faktor utama yang dapat mempengaruhi perilaku anak.

Berdasarkan hasil wawancara juga diketahui selain keluarga yang bermasalah, faktor pendidikan dalam keluarga juga mempengaruhi munculnya perilaku bullying pada anak. Berdasarkan 
Trisca Camelia, Eka Sari Setianingsih, Diana Endah H: Analisis Perilaku School Bullying di SD Muhammadiyah 17 Semarang

hasil wawancara dengan Bapak Sugiman selaku guru olahraga di SD Muhammadiyah 17 Semarang berpendapat bahwa pendidikan keluarga yang rendah kurang mengetahui trik-trik atau cara-cara menghadapi perilaku bullying karena kurangnya pengetahuan dibidang pendidikan maupun keagamaan. Berbeda dengan pendapat Bapak Sugiman, Ibu Ninik Riwayati berpendapat bahwa pendidikan keluarga tidak menjamin dalam peran mendidik anak, karena ada pula yang orangtua berpendidikan tinggi tetapi perilaku anaknya tidak baik.

Berdasarkan pendapat dari hasil wawancara tersebut dapat ditarik garis besar bahwa keluarga merupakan pendidikan pertama bagi anak. Perilaku anak pada dasarnya telah dibentuk didalam keluarga sehingga seharusnya baik keluarga yang memiliki tingkat pendidikan tinggi maupun tingkat pendidikan rendah dapat memberikan pengetahuan tentang perilaku yang baik dan perilaku yang buruk bagi anak.

\section{b) Faktor Lingkungan Sosial}

Berdasarkan sejumlah 35 siswa dengan 26 siswa laki-laki dan 9 siswa perempuan menunjukkan hasil angket siswa sebanyak 53,8\% (14 siswa) siswa laki-laki dan 44,4\% (4 siswa) siswa perempuan menyetujui pertanyaan "saya sering melihat tetangga bertengkar". Faktor lingkungan dapat mempengaruhi perkembangan perilaku anak sehingga dapat memunculkan perilaku bullying. Jika lingkungan sosial didominasi dengan masyarakat yang bermasalah seperti adanya perjudian, pertengkaran, suka bergosip, dan hal negatif lainnya maka orangtua bisa jadi mengikuti kebiasaan tersebut sehingga akan berdampak pada kurangnya perhatian pada anak maupun anak akan melihat perilaku-perilaku tersebut sehingga suatu saat dapat melakukannya. 
Trisca Camelia, Eka Sari Setianingsih, Diana Endah H: Analisis Perilaku School Bullying di SD Muhammadiyah 17 Semarang

Berdasarkan hasil angket siswa selain melihat [tetangga bertengkar, sebanyak 65,4\% (17 siswa) siswa laki-laki dan 33,3\% (3 siswa) siswa perempuan menyetujui pernyataan "saya sering mendengar tetangga saya mengatakan kata-kata kasar (memaki, mencela) dan saya menirukannya". Berdasarkan pernyataan tersebut dapat terlihat bahwa perilaku bullying siswa juga terpengaruh dari lingkungan sosial. Mengatakan kata-kata kasar merupakan bentuk perilaku bullying verbal. Pembentukan perilaku anak biasanya berdasarkan apa yang mereka lihat dan yang mereka dengar, sehingga perilaku bullying juga dapat terbentuk akibat mereka meniru lingkungan sekitar.

Lingkungan disekitar rumah siswa SD Muhammadiyah 17 Semarang dapat dikatakan lingkungan rumah yang baik dengan kondisi yang aman. Berdasarkan hasil wawancara dengan orang tua siswa yaitu bapak Muhajir yang beralamat di Jl. Medoho mengatakan bahwa lingkungan sekitar rumahnya terdapat banyak kegiatan agamanya (lingkungan Religius) dan lingkungannya aman.

\section{c) Faktor Teman Sebaya}

Teman sebaya adalah anak-anak atau remaja yang memiliki usia atau tingkat kematangan yang kurang lebih sama yang saling berinteraksi dengan teman-teman sebaya yang berusia sama dan memiliki peran yang unik dalam kebiasaannya. Teman sebaya merupakan teman sepermainan yang dapat memberikan pengaruh yang baik, tetapi juga dapat memberikan pengaruh buruk bergatung pada kepribadian masing-masing anak. Siswa kelas III di SD Muhammadyah 17 Semarang lebih suka bersosialisasi dengan teman sebaya, sehingga teman sebaya dapat menjadi teman bercerita bermain dan bergaul. Kurangnya keterbukaan terhadap guru dan orangtua membuat siswa lebih mempercayai teman sebaya dalam menceritaan apa yang dialaminya. 
Trisca Camelia, Eka Sari Setianingsih, Diana Endah H: Analisis Perilaku School Bullying di SD Muhammadiyah 17 Semarang

Berdasarkan hasil angket siswa, sebanyak 57,7\% (15 siswa) siswa laki-laki dan 33,3\% (3 siswa) siswa perempuan menyetujui pernyataan "saya menjahili teman saya akibat ajakan teman lainnya", serta sebanyak 38,5\% (10 siswa) siswa laki-laki dan 11,1 (1 siswa) siswa perempuan menyetujui pernyataan "saya memukul teman saya karena diperintah teman lainnya". Berdasarkan hasil persentase tersebut masih banyak siswa yang terpengaruh perilaku negatif teman lainnya.

\section{d) Faktor Psikologis}

Setiap siswa memiliki kepribadian yang berbeda-beda, kepribadian terbuka akan disenangi, mudah bergaul, maka mereka akan memiliki motivasi dan memiliki banyak teman. Seorang siswa yang berkepribadian tidak terbuka atau pendiam, sulit bergaul dan akan kurang disenangi oleh teman. Setiap siswa ada yang memiliki kepribadian yang baik dan ada yang kurang baik. Berdasarkan hasil angket siswa 53,8\% (14 siswa) siswa laki-laki menyatakan selalu ingin menjahili temannya. Sedangkan untuk siswa perempuan hanya $1(11,1 \%)$ siswa yang menyatakan hal tersebut. Juga sebanyak 11,5\% (3 siswa) siswa laki-laki menyatakan ingin memukul temannya meskipun tidak melakukan kesalahan. Sedangkan untuk siswa perempuan tidak ada yang menyetujui pernyataan tersebut.

\section{e) Faktor Media Sosial}

Media sosial merupakan alat untuk berkomunikasi dan berinteraksi, media sosial akan bermanfaat jika digunakan dengan benar dan jika salah menggunakan akan menyebabkan hal-hal yang tidak diinginkan seperti timbulnya perilaku bullying.

Siswa kelas III di SD Muhammadiyah 17 Semarang sudah mengenal adanya handphone namun sebagian yang memiliki handphone dan mengenal bahkan memiliki aplikasi dari berbagai macam media sosial seperti whatsApp, facebook dan instagram. 
Trisca Camelia, Eka Sari Setianingsih, Diana Endah H: Analisis Perilaku School Bullying di SD Muhammadiyah 17 Semarang

Aplikasi media sosial ini jika tidak dipantau pengawasan orang tua akan dapat menyebabkan munculnya perilaku bullying.

\section{Dampak Bullying}

Dari berbagai data yang diperoleh bahwa siswa kelas III SD Muhammadiyah 17 Semarang mengalami dampak dari bullying, dampak yang ditimbulkan ialah seperti trauma ketika dipukul, malu karena diejek, terluka akibat bullying fisik, dan adanya rasa takut untuk melaporkan pelaku bullying. Selain itu ada beberapa anak yang tidak ingin berangkat sekolah karena suka diejek oleh temannya dan juga ada beberapa anak yang mengaku nilai akademiknya merosot akiba menjadi korban perilaku bullying.

Siswa kelas III yang berjumlah 35 siswa yang terdiri dari 26 lakilaki dan 9 perempuan mengalami beberapa dampak bullying antara lain $77,8 \%$ (7 siswa) siswa perempuan merasa trauma ketika dipukul dan $53,8 \%$ (14 siswa) siswa laki-laki juga merasa trauma ketika dipukul. Sebanyak 33,3\% (3 siswa) siswa perempuan dan 19,2\% (5 siswa) siswa laki-laki merasa kurang bersemangat sekolah karena ancaman. Sebanyak $55,6 \%$ (5 siswa) siswa perempuan dan 61,5\% (16 siswa) siswa laki-laki merasa malu karena diejek. Sebanyak 55,6\% (5 siswa) siswa perempuan dan 41,4\% (12 siswa) siswa laki-laki merasa takut melaporkan ketika teman melakukan tindakan bullying. Sebanyak 55,6\% (5 siswa) dan 69,2\% (18 siswa) siswa laki-laki pernah terluka dan sebanyak 22,2\% (2 siswa) siswa perempuan dan 11,5\% (3 siswa) siswa laki-laki mengaku nilai akademiknya merosot akibat tindakan bullying.

Berdasarkan wawancara dengan kepala sekolah Ibu Umiyati, untuk mencegah dampak dari bullying yaitu dengan memberikan sosialisasi kepada anak dan ketika rapat wali murid, disampaikan bahwa perilaku bullying akan memberikan dampak negatif bagi siswa, sehingga

orangtua ketika dirumahpun akan ikut mengawasi anak agar tidak 
Trisca Camelia, Eka Sari Setianingsih, Diana Endah H: Analisis Perilaku School Bullying di SD Muhammadiyah 17 Semarang

melakukan tindakan bullying. Tidak berbeda dengan Ibu Umiyati selaku kepala sekolah, Ibu Ninik Riwayati juga menyampaikan untuk mencegah tindakan bullying yaitu mengajak siswa sharing untuk mempelajari siswa mengapa bisa terjadi hal tersebut (bullying).

Berdasarkan wawancara dengan guru dan kepala sekolah SD Muhammadiyah 17 Semarang, solusi yang dapat diberikan ketika adanya tindakan bullying baik fisik, verbal, maupun psikis, dapat dilakukan berdasarkan perilaku bullying yang terjadi. Apabila perilaku tersebut masih sebatas seperti mengejek, membentak, masih dapat diberikan arahan dari guru kelas maupun kepala sekolah bergantung pada sering tidaknyan perilaku tersebut dilakukan oleh pelaku. Namun apabila siswa sudah sampai memberikan dampak serius sampai korban terluka fisik hingga menimbulkan cidera serius maupun korban sampai tidak mau masuk sekolah, biasanya orangtua korban sendiri langsung melapor pada guru kelas maupun kepala sekolah sehingga pihak sekolahpun memanggil orangtua pelaku sehingga diselesaikan secara kekeluargaan.

\section{Kesimpulan dan Saran}

Berdasarkan hasil penelitian dan pembahasan dapat disimpulkan bahwa school bullying merupakan perilaku agresif atau tindakan yang bertujuan untuk melukai orang lain yang dilakukan secara sengaja ataupun tidak sengaja oleh siswa dilingkungan sekolah. Siswa dan siswi kelas III di SD Muhammadiyah 17 Semarang menjadi pelaku dan korban dari bullying. Siswa dan siswi menjadi pelaku dari bullying fisik seperti memukul, mendorong, menendang, serta memeras uang ,sedangkan bullying verbal meliputi membentak, mengejek, menggosipkan, serta memberi nama panggilan orang tua. Dan untuk bullying psikis meliputi mempermalukan, melakukan gerak tubuh mengancam, meneror dan mengancam.

Dampak yang ditimbulkan dari tindakan bullying ialah seperti trauma ketika dipukul, malu karena diejek, terluka akibat bullying fisik, dan adanya 
Trisca Camelia, Eka Sari Setianingsih, Diana Endah H: Analisis Perilaku School Bullying di SD Muhammadiyah 17 Semarang

rasa takut untuk melaporkan pelaku bullying. Selain itu ada beberapa anak yang tidak ingin berangkat sekolah karena suka diejek oleh temannya dan juga ada beberapa anak yang mengaku nilai akademiknya merosot akibat menjadi korban perilaku bullying.. Faktor yang menyebabkan bullying antara lain faktor keluarga, faktor teman sebaya, faktor lingkungan sosial, faktor psikologis dan faktor media sosial.

Berdasarkan hasil penelitian tersebut, maka saran yang dapat diajukan dalam penelitian ini adalah guru harus memahami tentang perilaku dan pencegahan bullying serta harus menetapkan peraturan mengenai bullying di sekolah secara merata, dan bagi orang tua yaitu dapat memberikan perhatian dan kasih sayang terhadap anaknya, maka orang tua dapat memberikan arahan serta pengawasan untuk anaknya agar tidak melakukan perilaku bullying. 
Trisca Camelia, Eka Sari Setianingsih, Diana Endah H: Analisis Perilaku School Bullying di SD Muhammadiyah 17 Semarang

\section{Daftar Pustaka}

Antasari. Menyikapi Perilaku Agresif Anak. Yogyakarta: Kanisius, 2006.

Chakrawati, F. Bullying Siapa Takut. PT Tiga Serangkai Pustaka Mandiri, 2015.

Hilmi, A. Mei 2. Tempo. Retrieved from Tempo.co: https://nasional.tempo.co/read/1084922/hari-pendidikan-kpai-84persen-siswa-alami-kekerasan-di-sekolah/full\&view=ok. Di unduh tanggal 29/10/2018 pukul 23:25 WIB, 2018.

Hurlock, E. B. Perkembangan Anak. Penerbit Erlangga, 1989.

Ihsan, F. Dasar-Dasar Kependidikan. Jakarta: PT Rineka Cipta, 2003.

Kluytmans, F. Perilaku Manusia (Pengantar Singkat tentang Psikologi). Bandung: PT Refika Aditama, 2006.

Syamsu Yusuf, A. J. 2009. Landasan Bimbingan \& Konseling. In A. J. Syamsu Yusuf, Landasan Bimbingan \& Konseling (p. 3). Bandung: PT Remaja Rosdakarya.

Sistem Pendidikan Nasional. Undang-undang No.20 Tahun 2003. Pasal 3.

Sistem Pendidikan Nasional. Undang-undang No.23 Tahun 2002. Pasal 54.

Wasono, H. T. 2018, Januari 29. Tempo. Retrieved from Tempo.co: https://nasional.tempo.co/read/1055133/siswa-sd-di-kediri-jadikorban-bullying-alami-infeksi-otak/full\&view=ok. Di unduh tanggal 29/01/2018 pukul 12:56 WIB

Wiyani, N. A. Save Our Children From School Bullying. Jogjakarta: Ar-Ruzz Media, 2014. 